Int. Archs Allergy appl. Immun. 1978;56:I-VI

\title{
Contents, Vol. 56, 1978
}

Vol. 56,1978

International Archives of Allergy and Applied Immunology

Founded 1950 by: D. Harley, P. Kallós, W. Löffler and F. W. Wittich Continued by: E. A. Brown (1952-1954), W. Kaufman (1955-1967), F. Hahn (1961-1972), H. C. Goodman (19631975)

Editors-in-Chief:

R. R. A. Coombs, Cambridge L. M. Lichtenstein, Baltimore, Md.

Contributing Editors:

G. Andres, Buffalo, N.Y.

E. L. Becker, Farmington, Conn.

W. E. Brocklehurst, Windlesham

A. Cerletti, Basel

B. Diamant, Copenhagen

P. Dukor, Basel

W. P. Faulk, Charleston, S.C.

M. Feldman, Rehovot

H. Fischer, Freiburg-Zähringen

R. van Furth, Leiden

P. G. H. Gell, Birmingham

H. Gewurz, Chicago, Ill.

I. Glazer, Tel Aviv

R. A. Good, New York, N.Y.

F. Hahn, Wittnau

L. Å. Hanson, Göteborg

P. Kallós, Helsingborg F. Milgrom, Buffalo, N.Y.

M. Hess, Bern

L. Hudson, Beckenham

H. Isliker, Lausanne

S. G. O. Johansson, Uppsala

E. A. Kabat, New York, N.Y.

K. Kano, Buffalo, N.Y.

R. Keller, Zurich

Ö. Ouchterlony, Göteborg

Z. Ovary, New York, N.Y.

P. Perlmann, Stockholm

E. Pick, Tel Aviv

K. W. Pondman, Amsterdam

R. E. Reisman, Buffalo, N.Y. 
M. Roitt, London

K. Rother, Heidelberg

Z. Trnka, Basel G. B. West, Epsom

D. S. Rowe, Lausanne

H. D. Schlumberger, Wuppertal A. Sehon, Winnipeg

E. Sorkin, Davos Platz

H. Storck, Zurich

A. Szenberg, Melbourne

A. Szentivanyi, Tampa, Fla.

T. B. Tomasi, jr., Rochester, Minn.

G. Torrigiani, Geneve

J. L. Turk, London

E. R. Unanue, Boston, Mass.

G. A. Voisin, Paris

B.H.Waksman, New Haven, Conn.

A. L. de Week, Bern

G. Wick, Innsbruck

S.Karger $\cdot$ Basel $\cdot$ München $\bullet$ Paris $\bullet$ London $\cdot$ New York $\cdot$ Sydney

All rights reserved. C Copyright 1978 by S. Karger AG, 4011 Basel

No part of this publication may be translated into (Switzerland), Arnold-Böcklin-Strasse 25

other languages, reproduced or utilized in any form or Printed in Switzerland by

Buchdrukerei Natio-

by any means, electronic or mechanical, including nal-Zeitung + Basler Nachrichten AG, Basel

photocopying, recording, microcopying, or by any information storage and retrieval system,

without permission in writing from the publisher.

Contents Vol. 56,1978

No. 1

Bach, M. K.; Bach, S.; Brashler, J. R.; Ishizaka, T., and Ishizaka, K.: On the Nature of the Pre sumed Receptor for IgE on Mast Cells. V. En hanced Binding of 125I-Labeled IgE to CellFree Particulate Fractions in the Presence of Protease Inhibitors 1

Coovadia, H. M.; Wesley, A.; Henderson, L. G.; Brain, P.; Vos, H. G., and Hallett, A. F.:

Alterations in Immune Responsiveness in

Acute Measles and Chronic Post-Measles

Chest Disease 14

Werner, C; Correa, M.-C, and Jeannet, M.:

Humoral and Cellular Immunity Against Allo-

geneic Antigens in Patients with Acute Leu

kaemia

24

Socha, W. W. and Moor-Jankowski, J.: Rh Anti

bodies Produced by an Isoimmunized Chim 
panzee; Reciprocal Relationship between

Chimpanzee Simian-Type Isoimmune Sera

and Human Anti-Rh0 Reagents 30

Krell, R. D. and Chakrin, L. W.: Pharmacologic

Regulation of Antigen-Induced Mediator Re

lease from Canine Lung $\quad 39$

Nagino, H.; Nomoto, K.; Kuroiwa, A.; Miya-zaki, S.; Goya, N., and Takeya, K.: Experimental

Models for Prevention of Graft-versus-Host Reaction in Bone Marrow Transfusion. II. Inability

to Prevent Graft-versus-Host Reaction in an H-2 Identical Combination .... 48

Miyazaki, S.; Nomoto, K.; Kuroiwa, A.; Goya, N., and Takeya, K.: Experimental Models for

Prevention of Graft-versus-Host Reaction in

Bone Marrow Transfusion. III. Reversible and

Irreversible Differentiation of Lymphocytes

Destined for Cytotoxicity to Effector Cells for

Splenomegaly 57

Beckett, R. C.; Bankhurst, A. D.; Van Epps, D. E.,

and Williams, R. C. jr.: Empiric Analysis of

the Interactions Involved in the Formation of

Fc Receptor Rosettes 65

Nordqvist, B. C. and Rosenthal, S. A.: Studies on

Contact Sensitivity to DNCB in Guinea Pigs

by the Macrophage Migration Test 73

Wilkie, B. N.; Nielsen, K. H., and Little, J.: Ex

perimental Hypersensitivity Pneumonitis:

Serum Immunoglobulins G1, G2, M, A and E

in Micropolyspora faeni Sensitized and De

sensitized Calves $\quad 79$

Short Communications

Datta, U.; Sehgal, S.; Mohapatra, S. B.; Aikat,

B. K., and Mehra, Y. N.: Correlation of Local

and Systemic Immune Cells in Tonsillitis Pa

tients 87

Archer, D. L.; Smith, B. G., and Bukovic-Wess,

J. A.: Use of an in vitro Antibody-Producing

System for Recognizing Potentially Immuno-

suppressive Compounds $\quad 90$

No. 2

Fällström, S. P.; Ahlstedt, S., and Hanson, L. Å.: Specific Antibodies in Infants with

Gastrointestinal Intolerance to Cow's Milk Protein. 97

IV

Contents

Yoo, T. J.; Kuo, C. Y.; Rajtora, D. W., and Richerson, H. B.: Studies of the Radioallergo-sorbent Test and the Lymphocyte Stimulation Index in Symptomatic Ragweed Pollenosis .. 106

Takigawa, M. and Hanaoka, M.: In vivo Matura

tion of B Cells in the Spleen of Nude Mice 
Following Administration of Bacterial Lipopolysaccharide 115

Zola, H.; Garland, L. G.; Cox, H. C, and Ad-cock, J. J.: Separation of IgE from IgG Subclasses Using Staphylococcal Protein A .... 123

Malavé, I.; Németh, A., and Blanca, I.: Immune

Response in Malnutrition. Effect of Protein

Deficiency on the DNA Synthetic Response

to Alloantigens 128

Ford, W. H. and Ashworth, L. A. E.: Effects of Variation in the Level of Haptenation of He-

terologous Protein Immunogen on Cellular and Humoral Responses of the Guinea Pig .. 136

Norman, M. E.; Mandle, R., and Nilsson, U. R.:

Further Studies of a Humoral Chemotactic

Abnormality in Glomerulonephritis 144

West, G. B.: Further Studies on the Structural

Requirements of Sugars as Antagonists of the

Changes in Vascular Permeability Produced

by Sugar Polymers in Rat Skin 155

Lee, W. Y. and Sehon, A. H.: Suppression of Reaginic Antibodies with Modified Allergens. I.

Reduction in Allergenicity of Protein Allergens by Conjugation to Polyethylene Glycol. 159

Casavant, C. H.; Wicher, V., and Wicher, K.:

Host Response to Treponema pallidum Infec

tion. III. Demonstration of Autoantíbodies to

Heart in Sera from Infected Rabbits 171

Diamant, B.; Kazimierczak, W., and Patkar,

S. A.: Mechanism of Histamine Release In

duced by the Ionophore X537A from Isolated

Rat Mast Cells. III. Actions of X537A on

Isolated Histamine-Retaining Granules, on a

Heparin-Protamine Complex Saturated with

Histamine and on Transport of Histamine

Into an Organic Phase 179

Short Communication

Behrendt, H.; Rosenkranz, U., and Schmutzler,

W.: Ultrastructure of Isolated Human Mast

Cells during Histamine Release Induced by

Ionophore A $23187 \quad 188$

No. 3

Lee, W. Y. and Sehon, A. H.: Suppression of Reaginic Antibodies with Modified Allergens. II. Abrogation of Reaginic Antibodies with Allergens Conj ugated to Polyethylene Glycol. 193

Lin, T.-M. and Halbert, S. P.: Immunological Relationships of Human and Subhuman Primate Pregnancy-Associated Plasma Proteins . 207

Milgrom, F. and Kano, K.: Comparison of

Various Procedures for the Detection of Anti

gen-Antibody Complexes 224

Birkeland, S. A. and Kristoffersen, K.: Cell-

Mediated Immunity in Pregnancy Evaluated 
Using Lymphocyte Transformation Tests and

Rosette Tests for T and B Lymphocytes. A

Cross-Section Analysis 232

Lilliehöök, B.; Blomgren, H., and Jacobsson, H.:

Induction of Specific Unresponsiveness

Against the $\mathrm{C} 3 \mathrm{H}$ Mis-Antigen in Mice. In

crease of Suppressive Capacity of $\mathrm{C} 3 \mathrm{H} \times$

CBA Fi-Lymphocytes after Sensitization

Against CBA Lymphoid Cells 238

Morito, T.; Tanimoto, K.; Horiuchi, Y., and

Juji, T.: Fc-Rosette Inhibition by Pregnant

Women's Sera and by Rabbit Anti-/1/8-Micro-

globulin 247

Bernard, C. C. A.; Mitchell, G. F.; Leydon, J., and Bargerbos, A.: Experimental Autoim

mune Orchitis in T-Cell-Deficient Mice 256

Nagai, H.; Kelly, K., and Sehon, A. H.: Antigen-, Anti-F(ab')2- and Anti-IgE-Induced Histamine

Release from Rat Mast Cells 264

Smolen, J. S.; Youngchaiyud, U.; Pichler, W. J.;

Binder, M.; Steffen, C, and Knapp, W.:

Studies on Rosette Formation of Human

Lymphocytes with Pig Red Blood Cells

Short Communication

Ottlecz, A.; Koltai, M.; Blazsó, G., and Minker, E.: Contributions to the Regulatory Role of Insulin in Inflammation and Anaphylaxis ... 284

No. 4

Grewal, A. S.; Rouse, B. T., and Babiuk, L. A.:

Characterization of Surface Receptors on

Bovine Leukocytes 289

Contents

$\mathrm{V}$

Anderson, R. E.; Hanahoe, T. H. P., and West, G. B.: Insulin and the Dextran Reaction in the

Rat 301

Nagaí, H.; Kelly, K., and Sehon, A. H.: The In

hibition of Histamine Release by Antiallergic

Drugs 307

Wick, G.; Brunner, H.; Penner, E., and Timpl,

R.: The Diagnostic Application of Specific

Antiprocollagen Sera. II. Analysis of Liver

Biopsies

316

Slavin, R. G.; Fischer, V. W.; Levine, E. A.; Tsai,

C. C, and Winzenburger, P.: A Primate Mo 
del of Allergic Bronchopulmonary Aspergil-

losis 325

Skinner, M. A.; Marbrook, J., and Baguley, B. C.:

Splenic Foci of Cytotoxic Lymphocytes in a

Graft-versus-Host Reaction 334

Rose, A. H. and Turner, K. J.: Effect of a Low Protein Diet on the Capacity of Mice to Express a Type I Hypersensitivity Response ... 344

Ahlmén, J.; Haglid, K.; Rönnbäck, L., and

Bucht, H.: Partial Purification of Human

Kidney Antigens 351

Benner, R. and Rozing, J.: Regulating Influence

of Transferred Immune Spleen Cells on the

Primary Response of Mice to Sheep Red

Blood Cells 358

König, W.; Czarnetzki, B. M., and Lichtenstein,

L. M.: Eosinophil Chemotactic Factor (ECF).

III. Generation in Human Peripheral Leuko

cytes 364

Short Communications

Offner, H. and Clausen, J.: The Enhancing Effect

of Unsaturated Fatty Acids on E Rosette

Formation 376

West, G. B.: Glucans and Dextrans in Rats and

Man 380

Wells, J. H.; Pollack, V. A.; Cox, C. P., and Cain,

W. A.: Studies of the Paw Test and Tumor-

Associated Immunosuppression in Mice $\quad 391$

Czarnetzki, B. M.; König, W., and Lichtenstein,

L. M.: Eosinophil Chemotactic Factor (ECF).

VI. Inhibitory Activity in Human Peripheral

Leukocytes 398

Stanworth, D. R.; Kings, M.; Roy, P. D., and Moran, D. M.: Investigation of the Reputed

Inhibition of the Prausnitz-Küstner Reaction by the Pentapeptide Asp-Ser-Asp-Pro-Arg ... 409

Johnson, H. G.; VanHout, C. A., and Wright,

J. B.: Inhibition of Allergic Reactions by

Cromoglycate and by a New Anti-Allergy

Drug U-42,585E. I. Activity in Rats 416

Baak, J. P. A.; Meijer, C. J. L. M.; Scheper, R. J.; Mullink, R., and Kater, L.: Production and

Traffic of B Lymphocytes in the Extracortical Central Area of the Guinea Pig Thymus .... 424

Balfour, A. H. and Jones, E. A.: Properties of

Receptors for IgG on Human Placental Cell

Membranes 435

Revell, P. A.: Effect of Long-Term Cyclophos-

phamide Treatment on $\mathrm{T}$ and $\mathrm{B}$ Lymphocytes

in Normal Guinea Pigs 443 
Sandberg, G.; Ernström, U.; Nordlind, K., and Fredholm, B. B.: Effect of Immunization on the Cyclic AMP Level and 3H-Thymidine Incorporation in Cultured Lymphoid Cells ... 449

Rothwell, T. L. W.; Love, R. J., and Evans, D. P.:

Studies on the Role of Histamine and 5-Hy-

droxytryptamine in Immunity Against the

Nematode Trichostrongylus colubriformis. IV.

Inhibition of the Expulsion of Worms Trans

planted into the Duodenum of Immune Gui

nea Pigs 457

Garcia, R.; Ureña, V.; Lahoz, C, and Oritz, F.:

Quantitation of IgE on the Basophil Surface

in Atopic Patient 463

Short Communications

No. 5

Manconi, P. E.; Fadda, M. F.; Cadoni, A.;

Cornaglia, P.; Zaccheo, D., and Grifoni, V.:

Subpopulation of T Lymphocytes in Human

Extravascular Fluids 385

Nihei, K. and Mizutani, H.: Human Colostral

Macrophages as Indicator Cells in Migration

Inhibition Test 470

Lichtenstein, L. M.; Sobotka, A. K.; Malveaux,

F. J., and Gillespie, E.: IgE-Induced Changes

in Human Basophil Cyclic AMP Levels 473

VI

Contents

No. 6

Johnson, H. G.; VanHout, C. A., and Wright,

J. B.: Inhibition of Allergic Reactions by

Cromoglycate and by a New Antiallergy Drug

U-42.585E. II. Activity in Primates Against

Aerosolized Ascaris suum Antigen 481

Luster, M. I.; Armen, R. C; Hallum, J. V.; Ahmed, A., and Leslie, G. A.: Immunoglobu-lin Class

Distribution of Measles Virus Antibodies in Serum and Spinal Fluids of Patients with Subacute

Sclerosing Panencephalitis ... 488

Spicer, B. A.; Ross, J. W.; Sharpe, T. J., and Smith, H.: Peritoneal Anaphylaxis in the Rat after

Sensitisation with Mouse Antiserum .. 493

Bray, M. A. and Franco, M.: Prostaglandins and

Inflammatory Cell Movement in vitro $\quad 500$

Borgers, M.; De Brabander, M.; Van Reempts, J.; Awouters, F., and Janssen, P. A. J.:

Morphological Evaluation of Oxatomide - a New Anti-Allergic Drug in Guinea Pig Anaphylaxis 507

Vijay, H. M.; Perelmutter, L., and Bernstein, I. L.:

Possible Role of IgG4 in Discordant Correla 
tions between Intracutaneous Skin Tests and

RAST 517

Noonan, F. P. and Halliday, W. J.: Studies of Contact Hypersensitivity and Tolerance in vivo and in vitro. I. Basic Characteristics of the

Reactions and Confirmation of an Immune

Response in Tolerant Mice 523

Halliday, W. J. and Noonan, F. P.: Studies of Contact Hypersensitivity and Tolerance in vivo and in vitro. II. Regulation by Serum Factors 533

Till, G.; Rother, U., and Gemsa, D.: Activation

of Complement by Radiographic Contrast

Media: Generation of Chemotactic and Ana-

phylatoxin Activities 543

Czarnetzki, B. M. and König, W.: Modulation of Eosinophil Chemotaxis and Eosinophil

Chemotactic Factor Release by Concanavalin A. 551

Short Communications

Barnett, J. B. and Wust, C. J.: Levels of Homo-

cytotropic Antibody in Hereditarily Asplenic,

Splenectomized and Normal Mice 558

Nakajima, S.; Nihei, K., and Hyodo, Y.: C3

Activator in Agammaglobulinemia 563

Book Reviews 94,287,383,479,566

Varia 566

Errata 96

Author Index 567 